\title{
Enterobacter cloacae
}

National Cancer Institute

\section{Source}

National Cancer Institute. Enterobacter cloacae. NCI Thesaurus. Code C86360.

A species of facultatively anaerobic, Gram negative, rod shaped bacterium in the phylum Proteobacteria. This species is motile by peritrichous flagella, oxidase, urease and indole negative, catalase positive, reduces nitrate, does not degrade pectate and produces acid from sorbitol. E. cloacae is associated with hospital-acquired urinary and respiratory tract infections and is used in industry for explosives biodegradation. 